\title{
Assessment of special populations: Interventions against women and children victims of violence
}

\author{
Randi M. Gumilang, Sai Handari \\ IAIN Samarinda \\ rmgumilang@gmail.com, saihandari7@gmail.com
}

Submitted: 04-02-2020, Revised: 28-04-2020, Accepted: 17-11-2020

\begin{abstract}
Assessment of Crucial Studies in an Effort to Protect Victims of Women's Opinions by the Integrated Service Center for Women and Children Empowerment (P2TP2A) as encouraging and focusing on problem assistance relating to women and children. The purpose of this study is to: (1) Describe and describe the use of assessment of interventions used by the Integrated Service Center for Women and Children Empowermen in East Kalimantan and; (2) Review the assessment of interventions used for women and children with special contributions by P2TP2A in East Kalimantan Province. This study uses descriptive qualitative research. Data collection techniques in this study used interviews, observation and documentation in various P2TP2A work areas in East Kalimantan Province. Includes areas of Samarinda, Bontang, East Kutai \& Kutai Kartanegara. The results of this study, namely: 1) Assessment of interventions used in P2TP2A East Kalimantan Province consists of a combination that collects data that provides an overview of the case, service delivery process and service follow-up plans. The purpose of the assessment is to obtain an overview, process (formative) and outcome (summative). 2) The assessment used still consisted of conventional assessments that were widely adopted by P2TP2A in East Kalimantan. In some cases, there needs to be special handling, so the assessment used is based on the psychologist or medical history and other assessments that suit the needs of the client with special contributions.
\end{abstract}

Keywords: Assessment; Special Populations; Women and Children

\section{Introduction}

The rise of cases of violence that occur in girls and children, causing misery or physical, sexual, psychological and economic difficulties. To get out of the defense cycle which turns into an endless circle, support is needed not only from the closest people, such as family but also from the government such as the Integrated Service Center for Empowering Women and Children (P2TP2A) and law enforcement. The Center for Integrated Services for Women and Children Empowerment is an organization consisting of implementing agencies, implementing agencies, and providing complementary services for victims of covering rehabilitation, social rehabilitation, social reintegration and health assistance and assistance.

P2TP2A in East Kalimantan Province, covering the areas of Samarinda, Bontang, East Kutai \& Kutai Kartanegara as regional technical implementing units engaged in the protection and empowerment of women, including assessments or pioneers that support women and children who are victims of violence. Assessment is the most important thing to do. With regard to the many benefits obtained both obtained to identify, analyze, and diagnose the initial difficulties collected by the Individual (Nuradhawati, 2018). Implementation and assessment process for a counselor is an activity that is generally carried out from the beginning of the counseling process, starting from making work programs to diagnosing individual or group problems. Assessments in conventional applications or 'conventional assessments' are under the auspices of psychological theories that are structural, positivistic, behavioristic which in their processes rely solely on the calculation and processing of numbers solely (Paschali et al., 2020). Interpretations carried out in 'conventional assessments' are always guided by agreements that have been predetermined and cannot be approved (Meng, 2017). 
This is confirmed by the results of research in Samarinda on the assessment model used by the counselor. At the social welfare institution, the provision of services should be in the quantum questioning model but is more inclined to the procedural model. In this concept, the counselor has sought to determine the services available to be accepted or accessed by clients. A focus on receiving services results in the counselor tending to see the client as a victim rather than seeing the potential of the client. In addition, some counselors in Samarinda City are aware of the lack of knowledge they have related to the assessment so that the development of the assessment model cannot be carried out optimally. Seeing this there needs to be an assessment of each service or intervention provided in a special population.

Special populations that support a collection of individuals who have special characteristics, can consist of anything that can be questioned. For example, special populations in the form of groups that have physical/mental/difficult disabilities such as Children with Special Needs, victims of violence, sufferers of acute illness (Chavez et al., 2018). It can also be classified as Individuals who do not have a place to live (homeless) or a group of people who experience Termination of Work which is attached to a complicated problem so as to limit/hinder its self-development. It also includes individuals with specific trauma problems due to various problems in their lives, such as victims of domestic violence and victims of sexual violence.

The application of the assessment to this specific participation is strived to be effective and right on target so that it can analyze and act on behalf of the main to be able to facilitate what happened. This is discussed with research that says the importance of institutions that support women's empowerment and child protection (Pambudi \& Astuti, 2016). Supported by other research that says the implementation of empowerment programs for women victims of violence must focus on the quality of interventions, facilities and infrastructure (Ibrahim et al., 2019).

Special population assessments are urgently needed on women and children who have an interest in the household or because of section violence. Traumatic problems that occur in women and children with this case will continue to imprint results not in accordance with the results of the diagnosis This is what makes the assessment effort becomes crucial in the handling of individual problems. Related, in this article discuss more the assessment of special participants.

\section{Methods}

This study uses a qualitative research design with a description. Data collection tools using interview, observation and documentation techniques. In this study, a special study that discusses women and children discussing the problem of crisis (domestic violence and sexual violence) conducted for women around 20-28 years and boys and girls both called for 4-8 years. From data sources Obtained from the head of the institution, counselors, administrative staff, and special participation (women who participated in 20-28 years and male daughters both girls who reached 4-8 years old) stored in East Kalimantan specifically at the Provincial Level, City of Balikpapan, East Kutai Regency, Kutai Kartanegara District and Bontang City. Furthermore, data analysis techniques use triangulation. 


\section{Results and Discussion}

1. Service Description for Special Populations in East Kalimantan Province

Services for Residents in East Kalimantan are held by all relevant institutions. In this article, special participation discusses the subject of women and children who solve a crisis situation (domestic struggle and sexy violence) which supports women around 20-28 years and both boys and girls who are called 4-8 years. Related, this concept is devoted to services for women and children who fix crises at P2TP2A institutions.

As an initial description, P2TP2A of East Kalimantan Province has existed since 2009, as a social service and assistance when overcoming the challenges of overcoming problems involving women as an extension of the Center with the assistance and assistance in the Regencies and Cities in the Provincial Region East Kalimantan provides direct assistance to clients who come to the location when they need help. Related, the focus of the service is not only limited to organizing training in collaboration with the center but directly participating in the process given by P2TP2A, East Kalimantan Province has an extension in every district and city in East Kalimantan. There are around eleven P2TP2A Cities and Regencies located, namely P2TP2A in Balikpapan City, Samarinda City, Bontang City, East Kutai Regency, Tanjung Redeb Regency, Tanjung Selor Regency, Kutai Kartanegara Regency, Mahakam Ulu Regency, North Penajam Paser Regency, Paser Regency, Regency West Kutai.

The various activities carried out, provided specifically for services provided specifically for information services and data provision; medical and psychological referral services; counseling services; legal advocacy services; and safe home services for women in Figure 1.

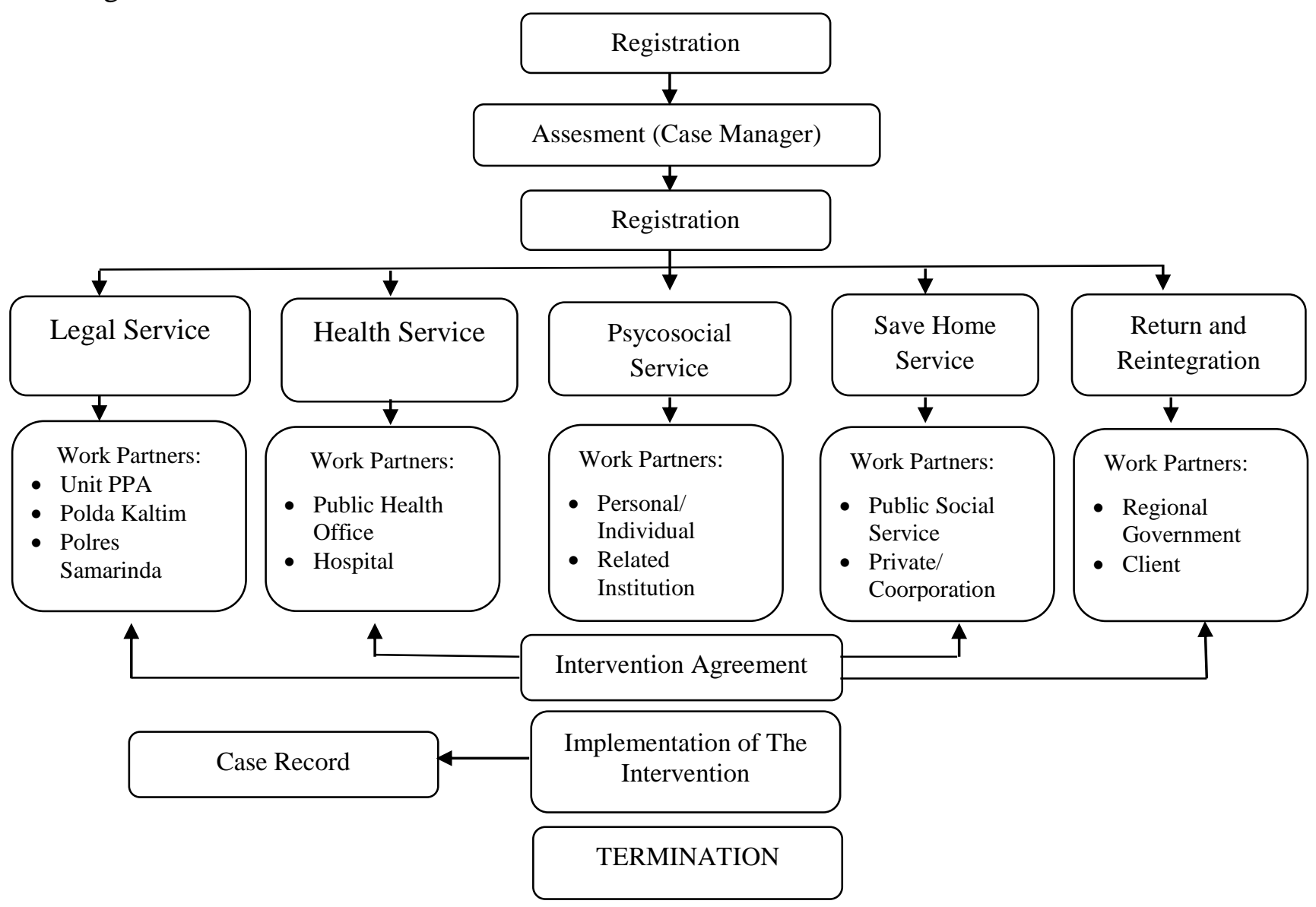

Figure 1. The flow of Victim Services for Special Populations 
Specifically, research specifically for women that discusses research on women and children who obtain knowledge about the experience of (a) (b) intercourse; (c) drug abuse by women and minors; (d) trade; (e) sexy harassment; to (f) sexual abuse (Pebriaisyah \& Pinasti, 2019). Related, the process of services provided to special communities as given above can be described as follows:

a. Registration stage, Services provided to the public begins with the presence of reporting, both reported by the victim published, reporting from other people both the surrounding community, volunteers or the victim's family. At the time of reporting, the reporter will be directed to register first, which is included in the biodata of the reporter, victim, and perpetrator. At this stage, an initial assessment is also carried out to complete the initial data and initial identification.

b. In the assessment phase, in this task, the officers of P2TP2A more specifically provide direction in conducting conversations and also collect data on victims and protection. This stage will then provide an overview of the interventions or services that will be obtained by victims or donors.

c. The intervention plan stage, the results of the assessment are the basis of the implementation of the services to be provided. At this stage, the service provider will provide alternative services obtained by the client, and the client accepts to make a decision on what services will be taken. Decisions in planning are needed by the client with consideration of the sustainability of the services to be obtained by the client and the needs needed by the client. Related, the accuracy of taking service decisions taken must be based on client decisions.

d. Intervention services, After there is a decision from the client what services will be taken, then the service provider is provided for the client. During the service period, the provider does not need to be responsible, but always accompanies service interventions. These intervention services are tailored to the services taken and collaborate with partners. Needed, clients get satisfaction in the services provided. Before the intervention service continues, the client agrees to make an intervention agreement as a form of client responsibility as well as a provider for client confidentiality.

e. Termination or termination. There are several things that are finally resolved, namely: (1) the client has received the services needed and can be resolved (2) the absence of the client during the given grace period. For example, the absence of a client for three weeks in a row during the service agreement period; and (3) there is a decision to approve the client with other business partners. In this case, the provider becomes a remote evaluator to consider referrals to other parties who are more expert, such as legal entities, collaborators or psychologists and psychiatrists.

\section{Procedure for Assessment of Special Populations in the Province of East Kalimantan}

The concept of assessment is a concept that is oriented to complete data of an object and a particular problem. For the sake of complete data coverage, there are several techniques that can be used in combining the data. Associated with a variety of specialty that can be used to get holistic and complete results.

Regarding the procedures for implementation carried out on P2TP2A using a complete data form that contains all data about the development of the case carried out. In this context, assessments are also incorporated into a follow-up effort and evaluation of a case. Of course, the assessment is used in the form of a special format provided by 
institutions under the Ministry that has ISO. Furthermore, it can be developed based on the needs of each Regency and City.

In general, the assessment used in P2TP2A is a form of administration and also used to obtain the initial results to the end of a case. This assessment begins with the filling of biodata to find out who is the victim, protection and also the reporter. At this time, the officer will first fill in the whistleblower's identity and the whistleblower's involvement in the approved case. Technically speaking, filling this biodata is not only required on paper but must also be completed in general.

This section contains biodata or general details such as name, address, place of birth date and relationship of the reporter with the victim. On the identity of the victim and a discussion on the latest education, religion, occupation, understanding, marital status, number of children and relationship with the victim. This can be done in two ways, namely asking the reporters to fill in directly or fill in by the approval of the reporter and other supporting data (for example, administrative completeness from the police or other institutions).

Preliminary information about the complainant, the victim and also who provides an assessment for further discussion related to additional information regarding the description of the case. In this section, the officer will provide additional questions about the case that occurred at the date and time of the incident, the chronology of the case and the impact that was experienced when the case occurred. Impact here is an impact that can still be seen or accepted in general in accordance with and provided for the results of further observations or results based on the post mortem conducted.

After there is a description of the case then a decision is made on the services or interventions provided. At this stage, the client decides to make a decision about the service and what interventions will be carried out as a follow-up given. The determination of services will be carried out in accordance with the initial requirements that will be provided in accordance with the needs of the results carried out. Furthermore, the shape of the given image can be visualized in Figure 2.

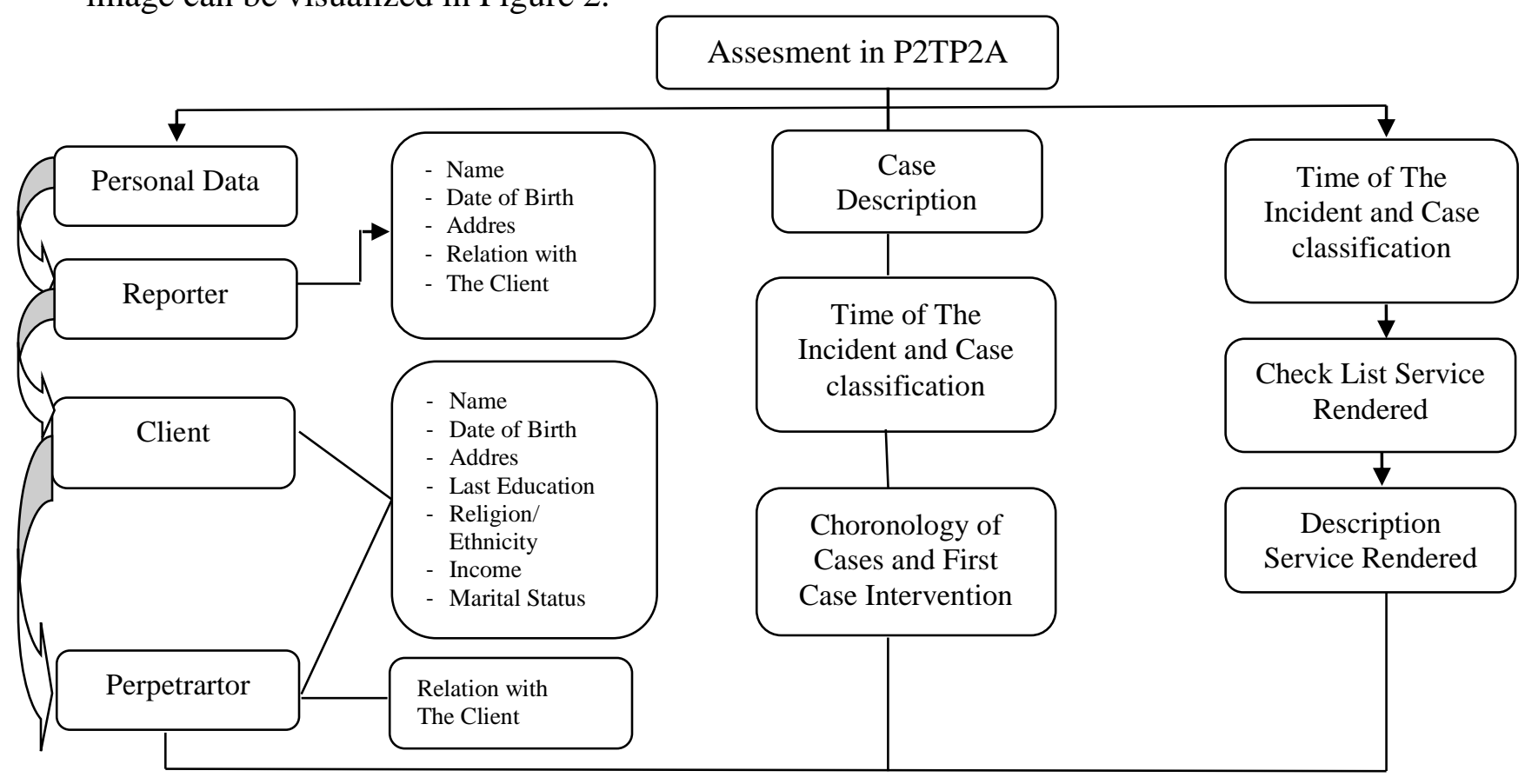

Figure 2. Rating of services at P2TP2A 
Of course in its implementation, this assessment is carried out continuously to achieve the desired goals, namely for renewal, formative and summative. Supposedly, the assessment carried out at P2TP2A cannot be specific to crises related to women and children who have succeeded in overcoming violence. This assessment is carried out to see a general description of the client's needs and if it requires special approval to direct directly to the competent party.

\section{Assessment of Special Populations}

The incidence in analyzing the time of diagnosis is important to determine the accuracy and also the consideration of interventions provided by the institution related to a particular case. In some cases, the institution must make a decision to help clients who come when the client makes the decision and the institution that facilitates providing services that are effective and right on target without discussing everything that was taken. Neither were cases related to the special population in the previous presentation (domestic violence of women and children which corrected good violence or sexual violence which increased the times of crisis).

Provision of initial assessment and accuracy in the complete diagnosis of traumatic traffic experienced by individuals experiencing trauma experienced by individuals (Roria, 2019). The diagnosis that can be made related to the diagnosis, which is done when discussing cases with this contribution must be completed as a diagnosis, namely an assessment that helps the discussion to assist in helping knowledge about research subjects, studies and research of interest, and to clarify misconceptions prior to the program or intervention. will be done, or done using a variety of certain ways or techniques (Vagi et al., 2016).

Assessments that are used to further see the traumatic side gained from a particular event in special populations need to be provided further. In particular, additional assessments are needed for initial repairs to victims that increase domestic challenges and section abuse that can improve psychological problems further due to trauma. For example, children who correct cases of sexy harassment such as sodomy cases by people they know, certainly need additional assessors to deal with the trauma they experience, because it will also affect their social, personal, and learning lives through their careers.

The assessments used today still provide a general picture in each case. As a form of study, the assessment used in the three sections related to identity, case description, and conversion was used. In the case description related to the time and date of the incident with a chronological description of the case. In special populations, assessments discussed with traumatic assessments can be added as a form of initial mental approval. This is related to the traumatic events that occurred during the crisis became a topic of discussion that has an interest. This is related to the difference between trauma experienced by entire groups of people, or trauma experienced by individuals.

Trauma as a result of problems that are both physical or mental will cause damage to the body or shock to the mind directly (Fast \& Collin-Vézina, 2019). Psychological trauma including emotional shock that has a lasting effect on personalities, such as tolerance, divorce, combat experience, civil disasters, and race or religious conflict will continue as the physical and mind released release emotional or mental repairs. A study says a certain degree of traumatic traits in certain individuals depends on the dynamics, duration, and severity of certain trauma, as well as the subjective experiences of individual victims (Niolu et al., 2018). 
In line with research that says individuals' past experiences also contribute to determining people's perceptions at the budget level and ability to respond (Nicol et al., 2016). Accordingly, based on the concept, aspects that determine (b) Physical; (c) emotional; (d) social; and (e) cognitive.

Related, in this context the assessment used can be developed based on indicators that become a traumatic reality regulated in (a) neurological; (b) Physical; (c) emotional; (d) social; and (e) cognitive. The existence of an appraiser by agreeing on this indicator will provide a concept that provides the interpreter used by the assessor used by officers by completing the traumatic indicator so that special assistance is needed. In more detail, this concept will be brought to the purpose of the assessment which specifically addresses the traumatic side that occurs to special participants. This concept also leads to discussion and understanding of the assessment used only for the purpose of conducting the discussion, not to the purpose of discussing formative or summative discussion.

The estimator used for specific participants specifically provides for the assessment carried out. The estimator carried out leads to the final goal as an enhancer that discusses the traumatic conversation that was developed not only to the extent agreed on the results as well as the process. This is supported by research which says that focusing on the objectives of the assessment will give consideration to a decision that focuses on providing services to clients (Dahnil et al., 2017). This is assumed to originate from stress enhancers for the client because psychological needs are unstable and require someone to decipher the stressors needed. Of course, decomposition of stressors can be done quickly and precisely. Estimated source of stressors by using an appropriate assessor as well. However, each person will have a different level. And become important in using the assessment that has been selected.

Furthermore, the assessment was issued as a substitute. At this stage, the assessment will provide three follow-ups as a follow-up or follow-up to the results of the assessment. Third. Based on the assessment that can be taken based on the results of the assessment, namely:

(a) The existence of advanced services as a result of the assessment

Services in an institution that are all integrated with partners as part of the needs of the Service will provide follow-up from the results of the assessment conducted. The results of the assessment can then be followed up by providing services needed by the client based on further analysis. Of course, the delivery of follow-up services must be based on the client's decision as a service user and the relevant institutions provide an assessment of services that can be used as an alternative to the services provided.

(b) Handover the case

If the assessment results or there is one that shows the facts that exist to be able to make it possible with the variety of services available in an institution. Thus, the institution can facilitate transferring clients to more competent institutions. As one example of an approved case by a minor, it can be transferred to a legal aid agency that has been designated as an agency's work partner. The decision in the transfer of this case also provides an appropriate alternative to resolve the problem or the case is resolved.

(c) Termination

This can be agreed based on the results of the assessment, the client does not take any decision in a problem or case involving a certain period of time. Thus, in cases where the resolution is unclear the institution has the right to be able to terminate the case handled as a 
form of commitment to the institution. Another condition that allows termination is the end of cases handled based on the services provided.

A well-controlled assessment will have a positive impact on the implementation and intervention of the Integrated Service Center for Women and Children Empowerment (P2TP2A) on victims of violence against children and women (Rafikah, 2017). Furthermore, this study found that the assessment was carried out to study a number of problems that needed to be done specifically, therefore the assessment was used in the history of psychologists or medical and other assessments that suit the needs of clients with special assistance.

\section{Conclusions and Suggestions}

The assessment used in P2TP2A of East Kalimantan Province consisted of a series of data collection that provided an overview of the case, the service delivery process and the service follow-up plan. With the implementation of the assessment get a picture of the assessment of interventions in a diagnostic, process (formative) and outcome (summative). The appraisers used still consist of conventional appraisers which are widely adapted by P2TP2A in East Kalimantan. This study aims to develop assessments for special communities on interventions and the application of making practical assessments for special communities on developing assessment research assessments for specific communities.

\section{References}

Chavez, A., Huang-Storms, L., \& Zuckerman, K. (2018). Special population consideration in ASD identification and treatment. In Trauma, Autism, and Neurodevelopmental Disorders (pp. 161-194). Springer.

Dahnil, F., Mardhiyah, A., \& Widianti, E. (2017). Assessment of supportive care needs in parents of children with Thalassemia. NurseLine Journal, 2(1), 1-10.

Fast, E., \& Collin-Vézina, D. (2019). Historical trauma, race-based trauma, and resilience of indigenous peoples: A literature review. First Peoples Child \& Family Review, 14(1), $166-181$.

Ibrahim, L. F., Seran, G. G., \& Pratidina, G. G. (2019). Implementasi Program pemberdayaan perempuan korban kekerasan dalam rumah tangga di Kota Bogor. Jurnal Governansi, 5(1), 89-97.

Meng, X. (2017). Designs of the psychological assessment and test system based on highlevel talent management. 2017 2nd International Conference on Education, Sports, Arts and Management Engineering (ICESAME 2017).

Nicol, A. L., Sieberg, C. B., Clauw, D. J., Hassett, A. L., Moser, S. E., \& Brummett, C. M. (2016). The association between a history of lifetime traumatic events and pain severity, physical function, and affective distress in patients with chronic pain. The Journal of Pain, 17(12), 1334-1348.

Niolu, C., Lisi, G., \& Siracusano, A. (2018). Trauma-related disorders: sexual abuse and psychiatric comorbidities. In Sexual Dysfunctions in Mentally Ill Patients (pp. 141-151). Springer.

Nuradhawati, R. (2018). Peran pusat pelayanan terpadu pemberdayaan perempuan dan anak (P2TP2A) dalam Pendampingan perempuan dan anak korban kekerasan dalam rumah Tangga (KDRT) di Kota Cimahi. Jurnal Academia Praja, 1(01), 149-184.

Pambudi, Y. D., \& Astuti, P. (2016). Peran badan pemberdayaan perempuan perlindungan anak dan keluarga berencana dalam perlindungan perempuan korban kekerasan berbasis gender di Jawa Tengah. Journal of Politic and Government Studies, 5(03), 329-347.

Paschali, M., Lazaridou, A., \& Edwards, R. R. (2020). Clinical and research tools for pain 
assessment. In Spine Pain Care (pp. 55-65). Springer.

Pebriaisyah, B. Z. F., \& Pinasti, V. I. S. (2019). Peran Pusat pelayanan terpadu perempuan dan anak korban kekerasan "Rekso Dyah Utami" dalam menangani kasus kekerasan seksual pada anak di Yogyakarta. E-Societas, 8(5).

Rafikah, R. (2017). Peranan pusat pelayanan terpadu pemberdayaan perempuan dan anak (P2TP2A) dalam menghapuskan kekerasan dalam rumah tangga (KDRT) di kota Bukittinggi. Islam Realitas: Journal of Islamic \& Social Studies, 1(2), 173-186.

Roria, R. (2019). Implementasi undang-undang nomor 35 tahun 2014 tentang perlindungan anak terhadap perlindungan hak-hak anak korban kekerasan seksual (studi di unit layanan terpadu perlindungan sosial anak integratif kabupaten Tulungagung). Sakina: Journal of Family Studies, 3(3).

Vagi, K. J., Brookmeyer, K. A., Gladden, R. M., Chiang, L. F., Brooks, A., Nyunt, M.-Z., Kwesigabo, G., Mercy, J. A., \& Dahlberg, L. L. (2016). Sexual violence against female and male children in the United Republic of Tanzania. Violence against Women, 22(14), $1788-1807$. 
